\title{
Werkenden in leerstand
}

Citation for published version (APA):

van Eldert, P., Fouarge, D., de Grip, A., \& Poulissen, D. (2017). Werkenden in leerstand. ROA. ROA Fact Sheets No. 004 https://doi.org/10.26481/umarof.2017004

Document status and date:

Published: 01/01/2017

DOI:

10.26481/umarof.2017004

Document Version:

Publisher's PDF, also known as Version of record

\section{Please check the document version of this publication:}

- A submitted manuscript is the version of the article upon submission and before peer-review. There can be important differences between the submitted version and the official published version of record.

People interested in the research are advised to contact the author for the final version of the publication, or visit the DOI to the publisher's website.

- The final author version and the galley proof are versions of the publication after peer review.

- The final published version features the final layout of the paper including the volume, issue and page numbers.

Link to publication

\footnotetext{
General rights rights.

- You may freely distribute the URL identifying the publication in the public portal. please follow below link for the End User Agreement:

www.umlib.nl/taverne-license

Take down policy

If you believe that this document breaches copyright please contact us at:

repository@maastrichtuniversity.nl

providing details and we will investigate your claim.
}

Copyright and moral rights for the publications made accessible in the public portal are retained by the authors and/or other copyright owners and it is a condition of accessing publications that users recognise and abide by the legal requirements associated with these

- Users may download and print one copy of any publication from the public portal for the purpose of private study or research.

- You may not further distribute the material or use it for any profit-making activity or commercial gain

If the publication is distributed under the terms of Article $25 \mathrm{fa}$ of the Dutch Copyright Act, indicated by the "Taverne" license above, 


\title{
Werkenden in leerstand
}

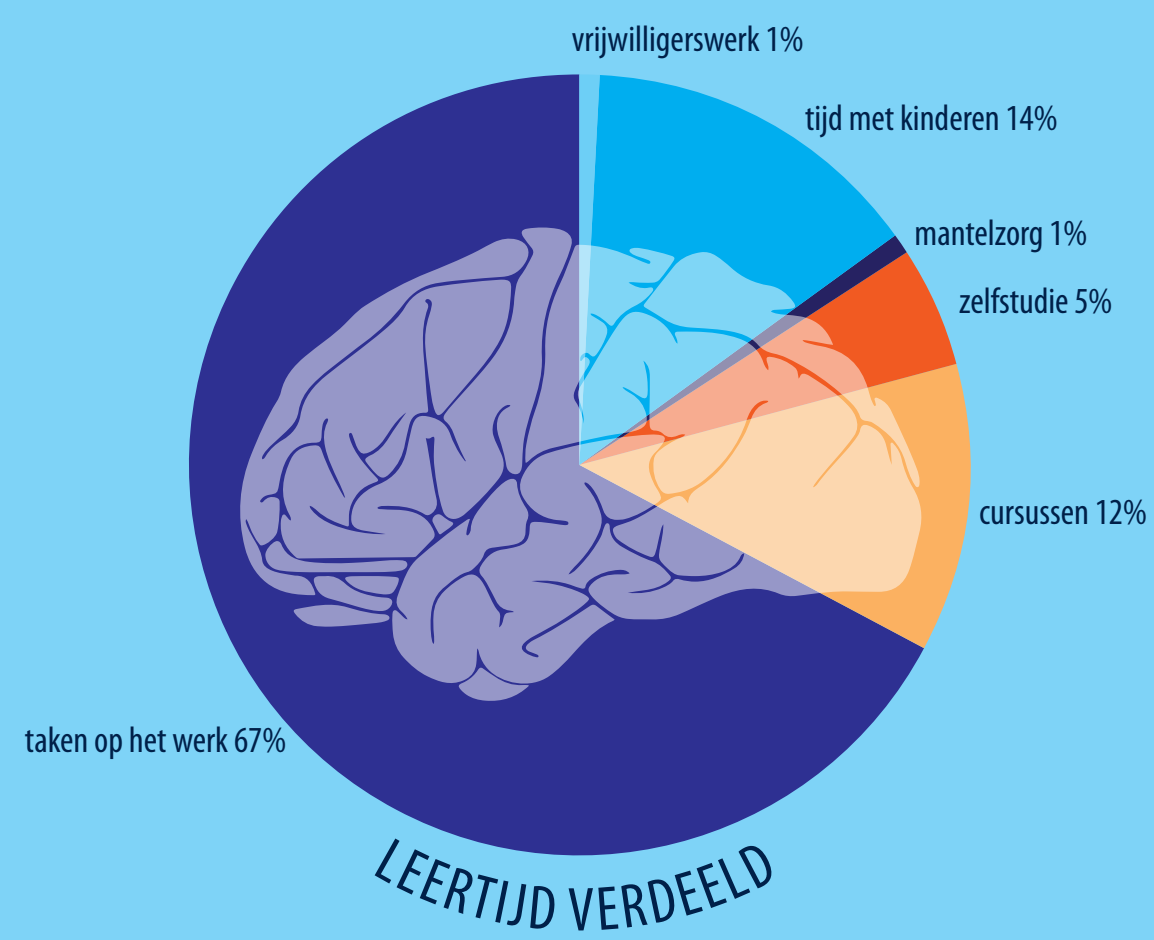

Bron: ROA Life Long Learning survey 2017

\section{ROA Fact Sheet}

\author{
ROA-F-2017/4
}

Researchcentrum voor Onderwijs en Arbeidsmarkt | ROA Research Centre For Education and the Labour Market / ROA 


\section{WERKENDEN IN LEERSTAND}

- WAARVAN LEER JE OP HET WERK?

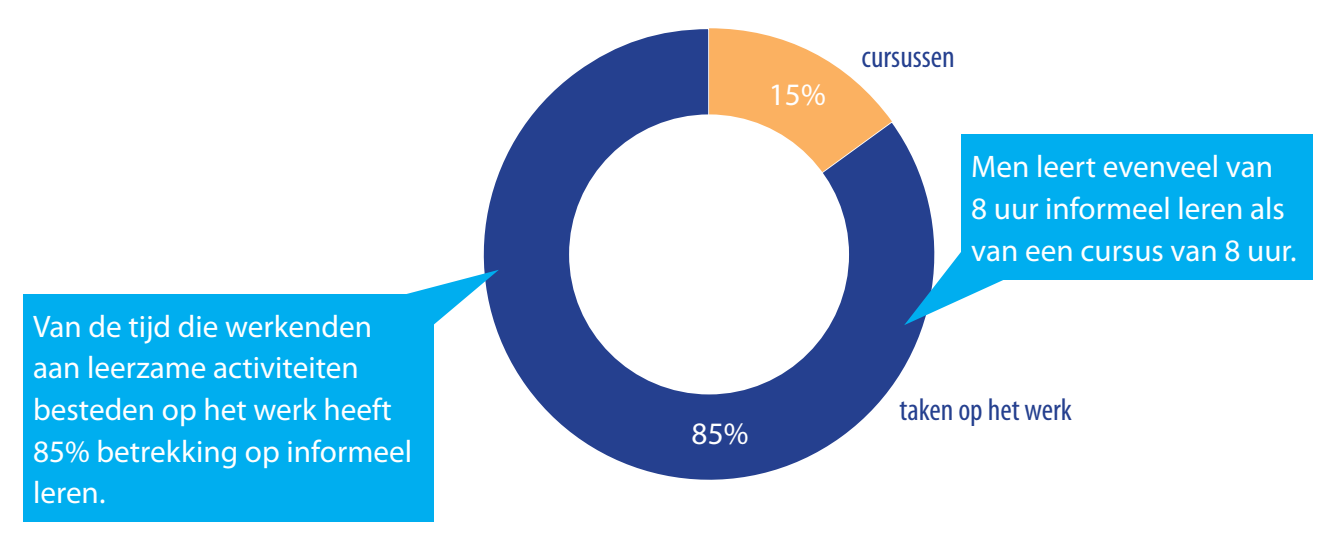

M CURSUS DEELNAME IN DE AFGELOPEN TWEE JAAR

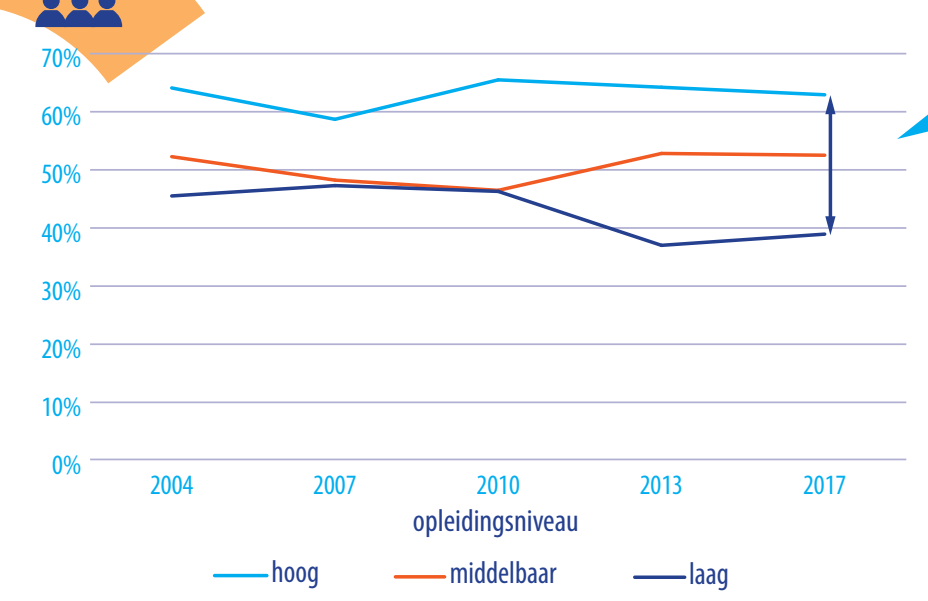

Kloof in cursusdeelname tussen hoog- en laagopgeleiden
groeit tussen 2004 en 2017 .
Percentage werkenden dat in de afgelopen 2 jaar een cursus of training heeft gevolgd:
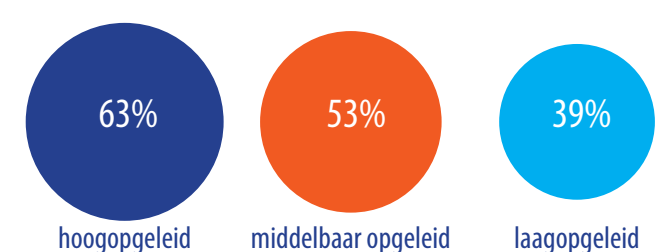

Een typische cursus:

- duurt 3 dagen van 7 uur

- wordt met een diploma/certificaat afgesloten (79\%)

- heeft betrekking op vakspecifieke vaardigheden (54\%)

- heeft een verplicht karakter $(41 \%)$

- wordt gevolgd ter realisatie van loopbaandoelen $(36 \%$

PE PERCENTAGE VAN DE WERKTIJD WAARIN MEN LEERT VAN TAKEN

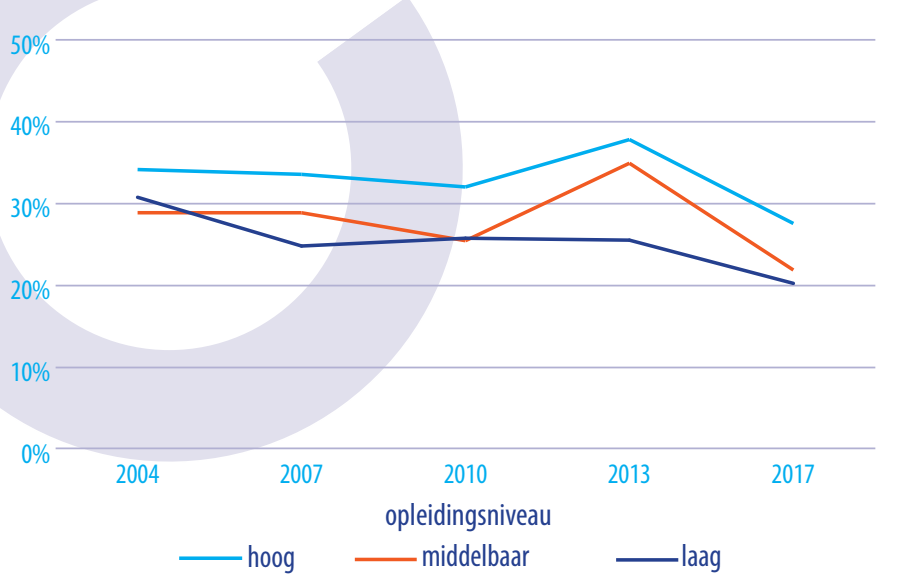

in men taken uitvoert waarvan men leert (=informeel leren op het werk):

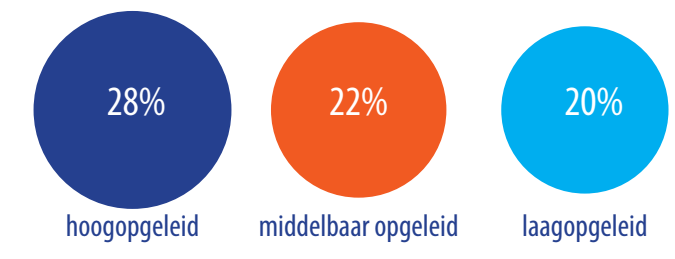

De omvang van informeel leren op het werk is tussen 2004 en 2017 afgenomen.

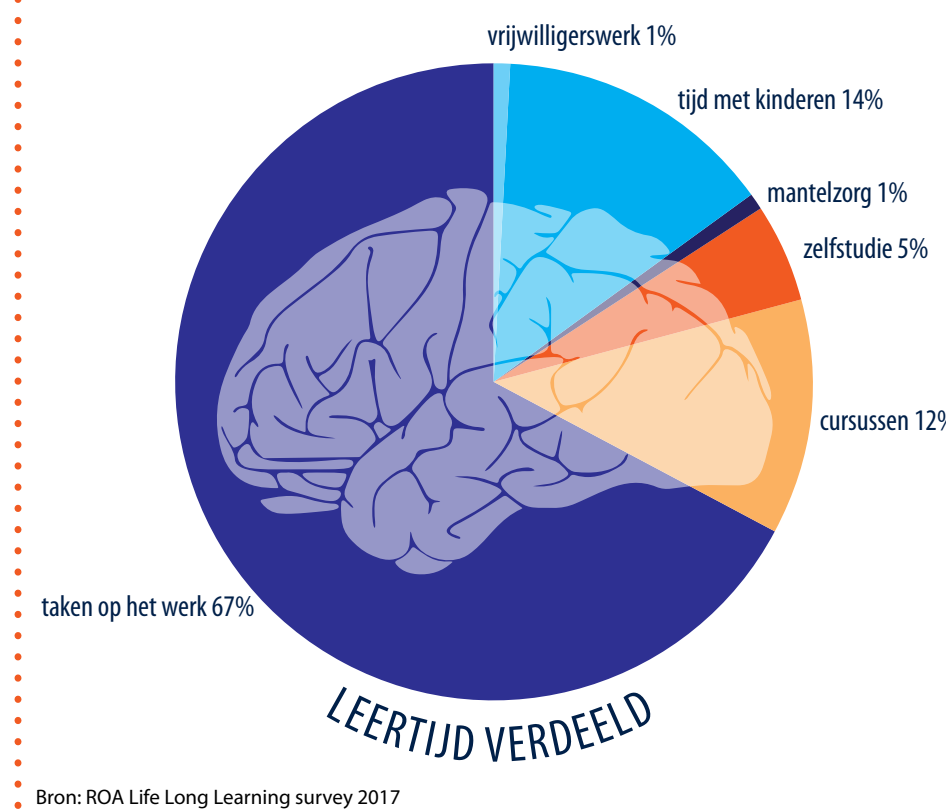

PERCENTAGE VAN DE TIJD WAARVAN $\Leftrightarrow$ MEN LEERT VAN ACTIVITEITEN BUITEN HET WERK

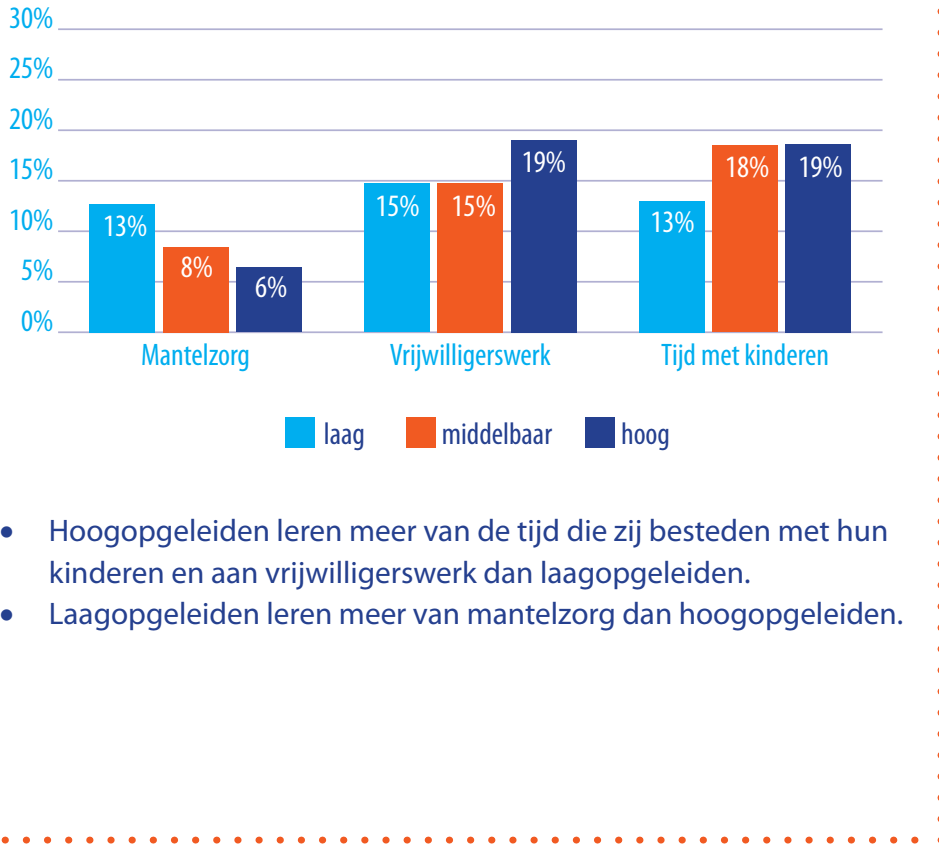




\section{Over de data:}

1. Het ROA brengt het formele en informele leren in kaart aan de hand van de ROA Levenslang Leren Enquête (ROA LLL).

2. De enquête is gehouden onder een representatieve steekproef van de Nederlandse beroepsbevolking in de jaren 2004, 2007, 2010, 2013 en 2017.

3. De data in deze factsheet hebben betrekking op personen die aangeven betaald werk te verrichten.

4. Deze versie van de factsheet is een herziene versie van de factsheet die in juli 2017 werd uitgebracht.

\section{Contactpersonen:}

Didier Fouarge, d.fouarge@maastrichtuniversity.nl

Andries de Grip, a.degrip@maastrichtuniversity.nl

Deze factsheet maakt onderdeel uit van het NRO project 'Levenslang leren en competentieontwikkeling'. (dossiernummer 405-16-402)

Researchcentrum voor Onderwijs en Arbeidsmarkt

Postbus 616

6200 MD Maastricht

$\mathrm{T}+31433883647$

F+31 433884914

secretary-roa-sbe@maastrichtuniversity.nl

www.roa.nl

Maastricht University

School of Business and Economics 